\title{
СТИЛІСТИКА ФАЗЕОЛОГІЗМІВ У СВІТЛІ ТИПОЛОГІЇ Г. П. ЇЖАКЕВИЧ (на матеріалі поеми М. В. Гоголя «Мертві душі»)
}

У науковому доробку відомого українського тінгвіста Галини Прокопівни Їжакевич стилістика посідає особливе місие й пов'язана з вивченням взаємовпливу української та російської мов. Однак проблематика стилістичних праць спрямована не тише на вивчення мовної взаємодії, а насамперед на збагачення однієї мови засобами іншої. У вивченні мови украӥнських та російських класиків Г. П. Їжакевич убачала великий сенс і неодноразово зверталася до ивого питання. Творчість М. В. Гоголя цікавила їі в аспекті оновлення української і російської мов експресивно-стилістичною тексикою та фразеологією. Новаторське поєднання двох мовних стихій в одному вислові українським письменником, що писав російською, розширювало уявлення про межі тітературної мови й розкривало творчі потенції кожної з мов.

Ключові слова: стилістика, Г. П. Їжакевич, творчість М. В. Гоголя, експресивно-стилістична лексика й фразеологія, взаємовплив української та російської мов.

Radchuk O. Stylistic of the Phraseological Units in Reference to G. P. Izhakevych Typology (a Case Study on the Poem "Dead Souls» by N. V. Gogol). In the scientific work of the famous Ukrainian linguist Halyna Prokopivna Izhakevych stylistics occupies a special place and is connected with the study of the Ukrainian and Russian languages interaction. But the focus of her stylistic works is aimed not only at the study of the linguistic interaction, but, primarily, at the enrichment of one language by means of another. G. P. Izhakevych saw a great significance in the study of the language of Ukrainian and Russian classics and repeatedly addressed this issue. N. V. Gogol's creativity interested her in the aspect of updating the Ukrainian and Russian languages with expressive and stylistic vocabulary and phraseology. The achievements of the scholar remain relevant nowadays. Moreover, the stylistics of phraseology has been developing intensively, and the theory has been constantly deepened and enriched with the practical developments of modern philological studies.

Actualization of phraseological units stylistic typology by $H$. P. Izhakevych is the aim of the paper, as well as representation of constant combinations types on the language material of N. V. Gogol's poem "Dead Souls". The tasks envisaged by the goal include: identifying the features of $N$. V. Gogol's style in the usage of different types of phraseology according to the classification by G. P. Izhakevych and linguistic analysis of contexts with phraseological units in different aspects. 
Research methods are determined by the purpose and the objectives of the paper: method of continuous selection and systematization of material for linguistic analysis, descriptive method and discursive analysis involved to establish and study the specifics of the permanent expressions functioning in the literary text "Dead Souls" by N. V. Gogol.

The innovative combination of two linguistic elements in one expression by a Ukrainian writer who wrote in Russian expanded the idea of literary language boundaries and revealed the creative potential of each language.

Keywords: stylistics: G. P. Izhakevych, N. V. Gogol's creative heritage, expressive and stylistic vocabulary and phraseology, the interaction of the Ukrainian and Russian languages.

\section{Вступ}

Творча спадщина Галини Прокопівни Їжакевич (1919-2003) - відомої української мовознавиці - уміщує багато праць зі стилістики української та російської мов, розробку нових підходів до дослідження мовної взаємодії у функційному аспекті. Пріоритетні теоретичне й практичне значення для науковиці мало спостереження над мовою відомих письменників. Креативність наукового доробку Г. П. Їжакевич полягає в тому, що вона дослідила вплив української мови на лексико-семантичне збагачення, демократизацію російської мови в різні історичні періоди, починаючи з епохи Петра I. Експресивно-стилістична лексика й фразеологія з творів українських майстрів словесності, за їі зауваженням, поповнювала словниковий склад російської мови різних стилів.

Здобутки вченої залишаються актуальними й сьогодні, а стилістика фразеології набуває інтенсивного розвитку, постійно відбувається поглиблення теорії і збагачення практичних напрацювань сучасних філологічних студій, про що свідчать останні публікації (Дядечко, Петренко, \& Прадід, 2012; Осіпова, 2019; Радчук, 2020).

Мета цієї розвідки - актуалізація стилістичної типології фразеологічних одиниць Г. П. Їжакевич та репрезентація типів сталих сполучень на мовному матеріалі поеми М. В. Гоголя «Мертві душі». До завдань, які передбачає поставлена мета, належать: 1) виявлення особливостей мовного стилю М. В. Гоголя у використанні різних типів фразеологізмів відповідно до класифікації Г. П. Їжакевич; 2) лінгвістичний аналіз контекстів з фразеологічними одиницями в різних аспектах (аксіологічному, культурологічному та інших). 


\section{Методи дослідження}

Методи дослідження зумовлені метою і завданнями статті: метод суцільного вибирання та систематизація матеріалу для лінгвістичного аналізу, описовий метод на підгрунті прийому інтерпретації, контекстуальний і дискурсивний аналізи залучено для встановлення і вивчення специфіки функціювання сталих висловлювань у художньому тексті «Мертві душі» М. В. Гоголя.

\section{Виклад основного матеріалу}

Зауважмо, що «проблема всебічного вивчення художньо-мовленнєвого стилю письменника залишається на передньому плані філологічних розвідок. Це пояснює увагу сучасних філологів до художнього тексту, особливо прецедентного, і до творчої особистості, яка породжує цей текст. До переліку таких творів належить і поема «Мертві душі» М. В. Гоголя» (Радчук, 2009).

Г. П. Їжакевич наголошувала на тому, що «в мовному стилі Гоголя блискуче поєднались, синтезувались демократичні стилі російського просторіччя з літературно-книжним, а також зі стилями канцелярської, офіціально-ділової і публіцистичної мови» (Їжакевич, 1953: 44). Мовознавиця акцентувала увагу на тому, що М. В. Гоголь не лише черпав художньо-образні засоби із «животворного джерела загальнонародної мови» (там само), але й у такий спосіб впливав на удосконалення загальнонародної мови, що виявилося в поєднанні стилістично різних мовних одиниць, не відповідало загальновстановленим правилам сполучуваності елементів, які вживалися в мовленні.

Російська й українська мови легко вбирають мовні елементи одна одної, у такий спосіб взаємно оновлюються і збагачуються, тому що, за словами Г. П. Їжакевич, «близькі своїми граматичними структурами і основними словниковими фондами російська і українська мови розвиваються в найтіснішому історичному й культурному взаємозв’язку» (Їжакевич, 1953: 45). Це підкреслює наявність спільних уживань фразеологізмів двох мов у просторіччі.

Влучне використання експресивних художньо-образних засобів, рис яких набувають фразеологічні одиниці в контекстах М. В. Гоголя, стає скарбницею народного гумору. Найрізноманітніші його відтінки (від насмішки до сарказму), але завжди сміх крізь сльози, утілюють народність творів М. В. Гоголя, передають його любов до свого народу 
та до своєї мови. Українець за походженням, хоча й писав російською, уводив українізми до текстів своїх творів.

Філологиня Г. П. Їжакевич зазначає, що, хоча вживання елементів української мови в прозі М. В. Гоголя $є$ фрагментарним та інколи випадковим, безумовно, «вони органічно входять в структуру гоголівської мови і виступають як невід'ємна частина його мовного стилю» (Їжакевич, 1953: 49).

Гоголівські художні тексти вирізняються насиченістю народною розмовною лексикою і фразеологією, причому ідіоми виявляються здатними й потенційно гнучкими до розширення та інтерпретацій. Однак Г. П. Їжакевич зауважує, що «Гоголь вводить українізми в мову своїх творів з великою обережністю, він чуло прислухається до вимог читача, до того, як саме буде сприйняте ним те чи те українське слово» (Їжакевич, 1953: 51).

Намагаючись розкрити психологію персонажів, їхній фізіологічний стан, щоб представити повну портретну характеристику, письменник добирає фразеологічні звороти. Це сприяє найточнішому відтворенню людських особистостей. I навіть за одним фразеологізмом можна впізнати героїв «Мертвих душ».

Фразеологізми несуть на собі значне стилістичне навантаження і мають гумористичне спрямування. «Отже, засвоївши цей словниковий засіб гумору на українському мовному матеріалі, Гоголь продовжує успішно користуватися ним і на матеріалі російської мови», - пише професор Г. П. Їжакевич (Їжакевич, 1953: 54).

М. В. Гоголь до описів у «Мертвих душах» активно залучає народні висловлювання, а також утворює за аналогією й індивідуальноавторські. Чимало фраз і словосполучень поеми стали афоризмами. У поемі «Мертві душі» письменник уживає різні за формою і за функціями сталі словосполучення.

Г. П. Їжакевич указує на те, що «фразеологізми здавна вважають однією із специфічних рис кожної мови. Містячи у собі велику силу експресії і емоційної наснаги, вони є яскравим виявленням зображальних і естетичних якостей мови» (Їжакевич, 1971: 13). У поемі «Мертві душі» М. В. Гоголь продемонстрував не лише здатність сталих висловів до переміщення в різні функційні стилі, а й те, що вони набувають різних відтінків гумористичного забарвлення. 
Наш аналіз стилістичної неоднорідності фразеологізмів спирається на класифікацію Г. П. Їжакевич, яку засновано на функційно-стильовому використанні стійких поєднань. Лінгвістка виділила такі групи фразеологізмів: розмовно-побутові, народно-поетичні та книжні. Водночас науковиця підкреслює можливості переходу функційно стійких сполучень з образно-виразної системи одного стилю в інший (Їжакевич, 1971). Детально розроблена типологія представлена у фраземіці як класифікація фразеологічних висловів з огляду на їх фіксацію за певними функційними стилями з урахуванням їхніх експресивно-стилістичних характеристик.

У виокремленні розмовно-побутових фразеологічних одиниць науковиця послуговується тим, що «основними сферами вжитку розмовно-побутових фразеологізмів $є$ усне побутове мовлення та художня література, у якій ці сталі словосполучення використовують 3 метою художнього відтворення розмовної мови (як в авторських текстах, так і в мові персонажів), типізуючи та індивідуалізуючи їі» (Їжакевич, 1971: 15). М. В. Гоголь уживає розмовно-побутові фразеологізми в поемі «Мертві душі» для найточнішого відтворення мовного середовища, передавання типовості ситуації.

Про належність фразеологізмів до певного типу іноді вказує і сам автор. Наприклад, в описовому фрагменті комічно репрезентується відсутність зовнішньої краси персонажів Одни только частые рябины и ухабины, истыкавшие их (черты лица - О. Р.), причисляли его кчислу тех лии, на которых, по народному выражению, черт приходил по ночам молотить горох (Гоголь, 1959: 240). Фразеологічна одиниця черт горох молотил, що зафіксовано словниками, трансформується у вислів черт приходил по ночам молотить горох. Навряд чи цей варіант виник по народному выражению, як стверджує сам М. В. Гоголь. Змінений і розширений лексично варіант народного вислову надає опису іронічної експресії та стає індивідуально-авторським.

У створенні портрета Плюшкіна автор застосовує фразеологізм, що підкреслює таку деталь, як відсутність зубів у персонажа: $\mathrm{Ha} э$ это Плюшкин что-то пробормотал сквозв губы, ибо зубов не было, что именно неизвестно, но, вероятно, смысл был таков: “А побрал бы тебя черт с твоим почтением!» (Гоголь, 1959: 126). Авторське переосмислення і зміна лексичного наповнення фразеологічного звороту бормотать сквозь зубы (Фразеологический словарь, 1986: 177) 
замінюється іронічним висловом бормотать сквозь губы з відповідним поясненням причин такої заміни. У цьому самому контексті $є$ ще одна фразеологічна одиниця, що передає обурення, досаду героя, домислюється після виконаної дії вже іншим персонажем - Чичиковим. Мовна партія Плюшкіна має гумористично-зневажливий характер. Стійкий емоційний вислів з розмовно-побутового мовлення черт побери! розширюється до цілого речення та відбиває повсякденний мовний досвід, можливо, і самого автора. Уживання в одному контексті кількох перефразованих фразеологічних одиниць підсилює комічний ефект. Подібні експресивно-емоційні вислови перенесені на сторінки поеми «Мертві душі» з розмовного мовлення і стають засобом вираження авторського ставлення до своїх персонажів, передавання атмосфери комунікативної ситуації.

Наведені приклади стійких словосполучень, що притаманні першому типу фразеологізмів за класифікацією Г. П. Їжакевич, підтверджують тезу мовознавиці про те, що "розмовні фразеологізми $€$ одним із засобів створення образів персонажів художнього твору, підкреслення окремих рис характеру, оцінки певних негативних чи позитивних вчинків; розмовна фразеологія надає широкі можливості для індивідуалізації й типізації мови, і нарешті вона є важливим засобом створення гумористичного ефекту» (Їжакевич, 1971: 17). Зауважмо, що зараз фразема черт побери! не належить до унормованої російської літературної мови, проте в XIX столітті завдяки М. В. Гоголю вона набула популярізації в культурно-освіченому середовищі.

Друга група фразеологізмів належить до народно-поетичних, або фольклорних. Г. П. Їжакевич у статті «Стилістична класифікація фразеологізмів» зазначає, що «народно-поетична фразеологія $\epsilon$ невід’ємним компонентом художньої творчості найвидатніших українських письменників-класиків» (Їжакевич, 1971: 17). Не оминає увагою такі сталі вислови й М. В. Гоголь у поемі «Мертві душі».

У наступному контексті образної інтерпретації та варіювання набуває фразеологізм и во сне не снились або во сне не видать, який, уважаємо, належить до народно-поетичної фразеології: А уж там в стороне четыре пары откалывали мазурку; каблуки ломали пол, и армейский штабс-капитан работал и душою, и телом, и руками, и ногами, отвертывая такие па, какие и во сне никому не случалось отвертывать (Гоголь, 1959: 175-176). Письменник перефразовує 
фразеологізм по-своєму, що підвищує експресивність контексту: какие и во сне никомунеслучалось отвертывать. Дієслово отвертывать метафорично розширює своє значення, набуває іронічної конотації, а нове оказіональне вживання сприяє утворенню комічних образів. У такий спосіб усталені вислови в описових контекстах М. В. Гоголя набувають гумористичного наповнення.

Малюючи портрет головного героя поеми «Мертві душі» Чичикова, автор в одному описовому контексті вживає п'ять стійких словосполучень, два $з$ яких ілюструють другий тип класифікації Г. П. Їжакевич. Наприклад, М. В. Гоголь використовує стійкий вислів ни жив ни мертв, що також належить до народно-поетичних: Уже стул, которым он вздумал было защзицаться, был вырван крепостными людьми из рук его, уже, зажмурив глаза, ни жив ни мертв, он готовился отведать черкесского чубука своего хозяина, и бог знает чего бы ни случилось с ним; но судьбам угодно было спасти бока, плеча и все благовоспитанные части нашего героя (Гоголь, 1959: 91). Фразеологізм ни жив ни мертв з властивою для народного мовлення образністю підкреслює незвичайний емоційно-психічний стан персонажа, коли той від страху втрачає здатність думати та діяти. У наведеному фразеологізмі зберігається слов'янська ментальність. У цьому контексті він набуває комічного забарвлення і стає засобом підвищення експресії.

Аналогічна фразеологічна одиниця $€$ і в українській мові: ні живий ні мертвици, що постає синонімом до таких сталих висловів, як мов неживици, ніби неживици, як мертвий. Вони значно поширені в українському мовленні та вживаються в чотирьох значеннях: «1) дуже повільно, без жвавості, без бадьорості; 2) дуже слабий фізично; 3) нерухомо, без зміни положення; 4) приголомшений чим-небудь, дуже наляканий, вражений, схвильований, заціпенілий» (Білоноженко, 1993, Т. 2: 540).

Зауважмо, що вислів отведать чубука був звичним у прозі XIX століття (трапляється в Пушкіна, Тургенєва, Баратинського), але в М. В. Гоголя, який доповнив його уточненням черкесский, використовується не в прямому значенні й тому набуває комічного забарвлення. Гоголівські оказіональні утворення настільки органічно поєднуються із загальномовними, що читач сприймає їх як щось неподільне. 
У розумінні Г. П. Їжакевич, гоголівська стилізація є складним оригінальним засобом використання фольклорного матеріалу. Мовознавиця пише: «Стилізація ця полягає у тому, що письменник дає дуже близькі до українських зразків аналогії, побудовані ним на матеріалі російської мови з використанням лише деяких окремих елементів української мови» (Їжакевич, 1953: 55), що підтверджує й аналіз прикладів.

Характерною рисою авторського стилю М. В. Гоголя є поєднання в одному описовому контексті для утворення образності кількох сталих висловлювань. У наведеному фрагменті тексту їх чотири. В еквівалентних фразеологізмах російської й української мов бог знает (рос. бог весть что, одному богу известно, бог знает что, один бог знает та ін.) та (укр. бог його знає що, один бог знає та ін.) номінативна одиниця бог є синонімом слова доля. Ця семантика зберігається з праслов'янської мови, тому зрозуміла усім слов'янам, що використовували ці прадавні слова як замінні в побуті й фольклорі.

У цьому самому гоголівському контексті вживається ще одне стале словосполучення судьбам угодно, в авторському творенні якого спостерігаємо вплив давньогрецької (Мойри) та слов'янської (суджениці) міфології. Зазначмо, що гоголівське словосполучення не зафіксовано у фразеологічних словниках, хоча $є$ відомим завдяки поемі «Мертві душі». Оказіональне утворення судьбам угодно сформовано на підгрунті фразеологізмів російської мови: искушать судьбу, игра судьбы, ирония судьбы, на произвол судьбы, какими судьбами (Молотков, 1986: 463) та как душе угодно 'як лише бажається, як подобається', сколько дуще угодно 'досхочу, вдосталь, без ніяких обмежень', сколько угодно 'дуже багато, у великій кількості', что душе угодно 'все, що бажається, що подобається’ (Молотков, 1986: 488-489). Функцію головного в гоголівському фразеологізмі має адвербіальний компонент угодно. Однак письменник робить акцент саме на лексемі судьбам, висуваючи ії на першу позицію в словосполученні. У російські мові синонімом до слова судьба є лексема доля, з якою в українській мові, на відміну від російської, є дуже багато фразеологізмів: випасти на долю, випробувати долю, втопити долю, жити та хвалити долю, зв'язувати долю, перепадати на долю, діставатися на долю, спокушати долю, доля відливається, доля зглянеться, доля маслом губи змастить, доля усміхнеться, доля обділила, доля скривдила, доля 
обернулася іншим боком, доля підставила ногу, доля привела, доля судила, доля увірвала нитку, доля послужила, лиха доля, щербата доля, доля занесла, чорна доля, щастя й доля (Білоноженко, 1993, Т.1: 260261). Слово доля збереглося в східнослов'янських і польській мовах, має праслов'янський корінь, належить до народнопоетичної лексики, що притаманна фольклорним творам. У контексті “всі ці долі" замінено одним словом-синонімом у множині (судъбам), що набуває іронічного стилістичного навантаження. За словами Г. П. Їжакевич, усна народна творчість постає «невичерпним джерелом» для письменників (Їжакевич, 1971: 18). Гоголівський словесний гумор бере витоки із цього джерела та наскрізь ним просочений, але навіть у цьому фразеологізмі відчувається сміх крізь сльози автора поеми.

До третьої групи фразеологізмів за стилістичною типологією Г. П. Їжакевич належать книжні, стилістично-виражальні функції яких є різноманітними. Аналізуючи цей тип сталих словосполучень, мовознавиця наголошує, що «найчастіше вони надають висловленню “високого” експресивно-стилістичного забарвлення, створюють загальний настрій урочистості, патетики, поетичності тощо. Проте в певних умовах, потрапляючи в словесне оточення зниженого стилістичного плану, книжні фразеологізми набувають протилежного стилістичного колориту, надаючи висловленню гумористичного чи навіть сатиричного забарвлення» (Їжакевич, 1971: 19). У поемі М. В. Гоголя якраз представлені стилістичні колорити контрастних планів фразеологізмів, лексика високого стилю, вкраплена в розмовну, утворює ефект несподіванки та комізму.

У створенні синкретичного опису групового портрету й інтер'єру спостерігаємо поєднання оказіонального вживання лексики високого стилю, що утворює авторські стійкі сполучення, з немаркованими стилістично словами, які набувають нового змісту в цьому творі: $3 а$ сим, подочедши к столу, где была закуска, гость и хозяин выпили как следует по рюмке водки, закусили, как закусывает вся пространная Россия по городам и деревням, то есть всякими соленостями и иными возбуждающими благодатями, и потекли все в столовую; впереди всех их, как плавный гусь, понеслась хозяйка (Гоголь, 1959: 101). Контекст уміщує груповий портрет (Чичикова, Собакевича та дружини Собакевича), а також інтер'єр будинку Собакевича. Опис розпочинається застарілим словом засим і переліком закусок, серед 
яких індивідуальне-авторське словосполучення иные возбуждающие благодати. В описі урочисте засим підкріплене дієприслівниковим зворотом подошедши к столу, раптово продовжується дієсловами розмовного стилю: выпили, закусили, потекли, понеслась. У словосполученні выпили как следует немаркована лексема выпили разом з уточненням как следует конкретизує не лише міру вжитого, але й впливає на семантику дієслова потекли (замість дієслова пошли). Дієслово течь у цьому контексті вжите в переносному значенні й набуває нової іронічної конотації. Дієслово понестись також ужито метафорично. Так на передній план виходить дружина Собакевича, що гордо несе себе у вітальню. Порівняння как плавный гусь у поєднанні з дієсловом понестись надає ії рухам величності, але слово гусь (домашній птах) знижує образ.

В описі привертає увагузастаріле слово благодать, що має декілька значень: 1. «милость, благоволение, дар, исходящие от бога»; 2. «благо, добро, благополучие» (Евгеньева, 1985, Т. 1: 93). Наведений фрагмент завдяки оказіональному поєднанню лексеми благодать з лексемою возбуждающие, набуває експресії та образності, а словосполучення засвоюється носіями мови як стале. Авторське словосполучення зберігає гоголівську іронію і може бути потрактоване лише як комічний сталий вислів, що належить до книжних фразеологізмів. Це ще раз підтверджує слова Г. П. Їжакевич про те, що «словесне оточення, контекст зумовлює поляризацію стилістичного функціонування однієї й тієї ж категорії фразеологічних сполучень» (Їжакевич, 1971: 19).

Особливістю художньо-мовного стилю М. В. Гоголя $€$ те, що письменник практично не використовує розповсюджених загальновідомих фразеологізмів у творенні опису інтер'єрів свої персонажів. Якщо навіть і вживає сталі вислови, то, як правило, наголошує на них, розміщуючи наприкінці контексту та надаючи їм основного семантичного навантаження, що в такий спосіб передає авторську модальність. Наприклад, це може бути глузливе ставлення автора: Избенка, понимаете, мужичья: стеклушки в окнах, можете себе представить, полуторасаженные зеркала, так что вазы и все, что там ни есть в комнатах, кажутся как бы внаруже, - мог бы, в некотором роде, достать с улицы рукой; драгоиенные марморы на стенах, металлические галантереи, какая-нибудь ручка у дверей, так что нужно, знаете, забежать наперед в мелочную тавочку, да купить на гроч 
мыла, да прежде часа два тереть им руки, да потом уже решиться ухватиться за нее, - словом: лаки на всем такие - в некотором роде ума помрачение (Гоголь, 1959: 210). Опис інтер'єру будинку вельможі представлено застосуванням прийомів “чужого слова” й контрастного протиставлення. Сатиричний контекст побудований на контрасті: избенка мужичья - драгоценные марморы на стенах, мелочная лавочка - металлические галантереи.

Авторській стилізації і вираженню суб’єктивної модальності сприяють вставні слова (понимаете, знаете, словом), суфікси, що мають зменшувально-зневажливу конотацію в цьому контексті (избенка, стеклушки, лавочку), проте акцент поставлений на кінець фрази - стійкий вислів (в некотором роде ума помрачение), яким завершується опис інтер'єру. Гоголь часто створює такі колоритні описи, уводячи їх у мову персонажів. Такі інтер'єри не просто запам'ятовуються, а стають трафаретними (покой известного рода, ниспосланный ему богом покой та ін.). Книжна фраза помрачение ума змінюється майстром словесності на оказіональне утворення, трансформація стосується передусім стилістичної забарвленості, надання вислову зниженої конотації.

Варто наголосити, що мовленнєві інновації М. В. Гоголя простежуються в усіх уживаннях фразеологічних одиниць. Їх важко розподіляти за типами, запропонованими професоркою Г. П. Їжакевич, оскільки вони не завжди відповідають запропонованим критеріям. Але, за словами мовознавиці, «стилістична класифікація фразеологізмів за джерелами їх виникнення надає можливість встановити основні функції сталих сполучень, які або закладені в самій природі фразеологізмів, або виникають у контексті внаслідок поєднання в ньому двох чи кількох сталих словосполучень різного, іноді протилежного стилістичного плану» (Їжакевич, 1971: 21), це по-перше. А по-друге, стилістична класифікація, за якою не завжди можна розподілити ужиті й трансформовані М. В. Гоголем фразеологізми, надає змоги ще раз підкреслити креативність мислення письменника та його феноменальність.

\section{Висновки}

Розмірковуючи в такий спосіб, ще раз підкреслимо, що фразеологічні одиниці відіграють особливу роль у формуванні мовної картини 
світу, оскільки їхня семантика тісно пов'язана з фоновими знаннями носія мови, культурно-історичними традиціями народу, який створює і використовує цю мову. Уживання фразеологізмів у художньому тексті, з одного боку, сприяє трансляції в концентрованому вигляді національно-культурного елемента реалій певного етносу, а з другого, - слугує засобом створення художньої індивідуально-авторської картини світу.

М. В. Гоголь на сторінках поеми «Мертві душі» активно залучає барвисті й соковиті народні вислови, а також моделює за аналогією індивідуально-авторські. Цим автор має на меті створення більш точних і яскравих художніх образів героїв; досягнення ефекту комізму в описі; надання національного колориту персонажу; вираженню авторського ставлення до героя, якого він описує, але найголовніше збагачує російську літературну мову, особливо в аспекті стилістики.

Отже, виразність і експресивність зорових образів, пропущених через свідомість автора в створенні портретів, посилюється шляхом включення в текст емоційних елементів розмовної мови. Використовуючи мовні одиниці з національно-культурною семантикою, до яких належать фразеологізми, М. В. Гоголь розширює межі національної мови. Фразеологічні одиниці, навмисно залучені до контексту, передають експресивно-емоційні відтінки значень понять, які вони вербалізують, мовних елементів, які вони заміщують, національну специфіку мовної картини світу носіїв української і російської мов, а також індивідуальне сприйняття світу та вербальну рефлексію письменника.

Аналіз фразеологічних одиниць уможливлює розкриття специфіки художньо-мовленнєвого стилю М. В. Гоголя, і тому подальше вивчення стилістики фразеологізмів буде спрямоване на дослідження перехідних і синкретичних типів сталих висловів за класифікацією, запропонованою Г. П. Їжакевич. З’ ясування функційно-стильових характеристик фразеологізмів доповнить теорію фразеології.

\section{ЛІТЕРАТУРА}

1. Білоноженко, В. (Ред.). (1993). Фразеологічний словник украӥнської мови. Київ: Наук. думка. 2. Дядечко, Л., Петренко, О., \& Прадід, Ю. (2012). 250 крилатих слів i зворотів М. В. Гоголя: Украӥнсько-російський тлумачний словник. Сімферополь: Изд-во Лемешко К. О. 3. Їжакевич, Г. (1953). Роль Гоголя в історії російсько-українських мовних зв'язків. Мовознавство, XI, 44-58. 4. Їжакевич, Г. (1971). Стилістична 
класифікація фразеологізмів. Українська мова і література в школі, 10, 13-21. 5. Осіпова, Т. (2019). Невербальна комунікація та своєрідність ї̈ омовлення в українському дискурсі: феномен вербалізації невербаліки. Харків: Вид-во Іванченка I. С. 6. Радчук, О. (2009). Реалізація суб'єктивної модальності в портретних та інтер'єрних описових контекстах (на матеріалі поеми М. В. Гоголя «Мертві душі»). (Автореф. дис. ... канд. філол. наук). Харків: ХНПУ імені Г. С. Сковороди. 7. Радчук, О. (2020). Методология лингвокультурного трансфера как новый подход к изучению паремий русского языка. В Новое в русской и славянской фразеологии. (с. 435-441). Olomouci: Univerzita Palackeho. 8. Евгеньева, А. (Ред.). (1985). Словарь русского языкка (Т. 1. А-Й). Москва: Русский язык. 9. Молотков, А. (Ред.). (1986). Фразеологический словарь русского языка. Москва: Рус. яз.

\section{ДЖЕРЕЛА}

1. Гоголь, Н. (1959). Полн. собр. соч. в 6 m. (Т. 5. Мертвые души). Москва: Худ. лит-ра.

\section{REFERENCES}

1. Bilonozhenko, V. (Ed.). (1993). Frazeolohichnyi slovnyk ukrainskoi movy [Phraseological Dictionary of the Ukrainian Language]. Kyiv: Nauk. dumka [in Ukrainian]. 2. Diadechko, L., Petrenko, O., \& Pradid, Yu. (2012). 250 krylatykh sliv $i$ zvorotiv M. V. Hoholia: Ukrainsko-rosiiskyi tlumachnyi slovnyk [250 Idiomatic Words and Phrases by M. V. Gogol: Ukrainian-Russian Explanatory Dictionary]. Simferopol: Yzd-vo Lemeshko K. O. [in Ukrainian and in Russian]. 3. Yizhakevych, H. (1953). Rol Hoholia $\mathrm{v}$ istorii rosiisko-ukrainskykh movnykh zviazkiv [Gogol's Role in the History of RussianUkrainian Language Relations]. Movoznavstvo - Linguistics, XI, 44-58 [in Ukrainian]. 4. Yizhakevych, H. (1971). Stylistychna klasyfikatsiia frazeolohizmiv [Stylistic Classification of Phraseology]. Ukrainska mova i literatura $v$ shkoli - Ukrainian language and literature at school, 10, 13-21 [in Ukrainian]. 5. Osipova, T. (2019). Neverbalna komunikatsiia ta svoieridnist yii omovlennia v ukrainskomu dyskursi: fenomen verbalizatsii neverbaliky [Nonverbal Communication and the Originality of its Pronunciation in the Ukrainian Discourse: the Phenomenon of Verbalization of Nonverbalism]. Kharkiv: Vyd-vo Ivanchenka I. S. [in Ukrainian]. 6. Radchuk, O. (2009). Realizatsiia sub'iektyvnoi modalnosti $\mathrm{v}$ portretnykh ta interiernykh opysovykh kontekstakh (na materiali poemy M. V. Hoholia «Mertvi dushi») [Realization of subjective modality in portrait and interieur descriptive contexts (on the material of "The Dead Souls" poem by N. V. Gogol)]. Extended abstract of candidate's thesis. Kharkiv: KhNPU imeni H. S. Skovorody [in Ukrainian]. 7. Radchuk, O. (2020). Metodologiya lingvokul'turnogo transfera kak novyj podhod k izucheniyu paremij russkogo yazyka [The Method of Cultural Transfer as a New Approach to Studyng Russian Paremia]. V Novoe v russkoj i slavyanskoj frazeologii - Novoe v russkoj i slavyanskoj frazeologii (pp. 435-441). Olomouci: Univerzita Palackeho [in Russian]. 8. Evgen'eva, A. (Ed.). (1985). Slovar' russkogo yazyka [Dictionary of the Russian Language]. (Vol. 1. A-J). Moskva: Russkij yazyk [in Russian]. 9. Molotkov, A. (Ed.). (1986). Frazeologicheskij slovar' russkogo yazyka [Phraseological Dictionary of the Russian Language]. Moskva: Rus. yaz. [in Russian]. 


\section{SOURCES}

1. Gogol', N. (1959). Polnoe sobranie sochinenij v 6 tomax [Complete collection of essays in 6 volumes] (Vol. 5. Mertvye dushi). Moskva: Hud. lit-ra [in Russian].

Радиук Ольга Вячеславівна - доктор філологічних наук, доцент, професор кафедри зарубіжної літератури та слов'янських мов, Харківський національний педагогічний університет імені Г. С. Сковороди; вул. Валентинівська, 2, м. Харків, 61168, Україна.

Tel.: +38-050-636-09-07

E-mail radcchuk.o.v@ukr.net

http://orcid.org/0000-0002-0343-6796

Radchuk Olga Viacheslavivna - Doctor of Philological Sciences, Docent, Professor at the Department of Foreign Literature and Slavic Languages, H. S. Skovoroda Kharkiv National Pedagogical University; 2 Valentynivska Str., Kharkiv, 61168, Ukraine.

Надійшла до редакції 7 вересня 2021 року

\section{CITATION}

ДСТУ 8302:2015: Радчук О. В. Стилістика фразеологізмів у світлі типології Г. П. Їжакевич (на матеріалі поеми М. В. Гоголя «Мертві душі»). Лінгвістичні дослідження: зб. наук. пр. Харк. нац. пед. ун-ту імені Г. С. Сковороди. Харків, 2021. Вип. 55. C. 115-128. DOI: https://doi.org/10.34142/23127546.2021.55.11

AРА: Радчук, О. В. (2021). Стилістика фразеологізмів у світлі типології Г. П. Їжакевич (на матеріалі поеми М. В. Гоголя «Мертві душі»). Лінгвістичні дослідження, 55, 115-128. DOI: https://doi.org/10.34142/23127546.2021.55.11 